\title{
Role of Emotional Factors in Learning Ukrainian as a Foreign Language at Higher School
}

\author{
Maria V. Tsurkan ${ }^{1}$, Anna Ilkiv², Oksana V. Maksymiuk ${ }^{3}$, Ivanna M. Struk ${ }^{3} \&$ Nataliya O. Shatilova ${ }^{3}$ \\ ${ }^{1}$ Department of Social Sciences and Ukrainian Studies, Higher State Educational Establishment of Ukraine \\ "Bukovinian State Medical University", Chernivtsi, Ukraine \\ ${ }^{2}$ Linguistic Department, Ivano-Frankivsk National Medical University, Ivano-Frankivsk, Ukraine \\ ${ }^{3}$ Department of Modern Ukrainian Language, Faculty of Philology, Yuriy Fedkovych Chernivtsi National University, \\ Chernivtsi, Ukraine \\ Correspondence: Maria V. Tsurkan, Bukovinian State Medical University, 2 Teatral'na Square, Chernivtsi, 58000, \\ Ukraine.
}

Received: June 10, 2020

Accepted: August 3, 2020

Online Published: August 4, 2020

doi:10.5430/ijhe.v9n7p130

URL: https://doi.org/10.5430/ijhe.v9n7p130

\begin{abstract}
The emotional component of the educational process has been stated to be an essential factor of the formation of interest of a foreign student to learn the Ukrainian language as a foreign one. As it is one of the effective ways to improve of effective studying, rationalization and optimization of teaching methodology, based on analysis of the row of theoretical, methodological and experimental investigations in branches of psychology, psycho-linguistics, intercultural communication and pedagogy of the higher school. It has been indicated, that the principle of emotionality belongs to some basic principles of personal-oriented approach to studying. The theoretical and methodological analysis of directions of emotions implementation has been conducted in the process of didactics and communication, productive ways and methods of actualization of emotional factor have been developed at classes of Ukrainian as a foreign language; cultural peculiarities of apprehension of the emotional component of the educational process by different ethnic groups have been investigated. It has been proved, that satisfaction or dissatisfaction of communicative need of an international student generates positive or negative emotions, which influence on communicative activity, educational process, and consequently, on the process of cognition as a whole. The empirical part of the investigation was conducted based on interrogation of foreign students of Higher State Educational Institution of Ukraine. It aimed to detect national features of emotions perception by representatives of different nationalities (students from India, Africa and Arabic countries). The analysis showed that such factors as students do not see their progress in learning a language, difficulties in language understanding on hearing, the great synonymous potential of Ukrainian language become reasons for negative emotions in the process of learning Ukrainian as a foreign language, i.e. disappointment, indifference, concern, fear, dispossession. The group of effective methods has been distinguished for the provision of learning emotionality: verbal, extra-linguistic and activity-role. It has been found out, that emotional stimulation belongs to effective methods of activation of communicative as well as educational activity as a whole. Methodological recommendations are distinguished, which are specific for teaching foreign students concerning the realization of the principle of emotionality in multicultural different ethnic students' audience.
\end{abstract}

Keywords: emotions, methods of emotionality, communicative act, personality-oriented approach, motivation, Ukrainian language as a foreign one, intercultural communication, a foreign student

\section{Introduction}

The problem of teaching (as for a teacher) and studying (as for a student) of a foreign language is a problem of modern psycholinguistics. Scientists focus their attention on the specificity of the process of origination of speech by the foreign communicator. This process differentiates from the mechanism of assimilation and production of native language, and it is closely connected with thinking, speaking and understanding. "In the process of learning a foreign language, educational (cognitive) activity forms, during which students master the language, develop speech mechanisms and speech acts in which the language functions. Speech activity is realized in specific actions and operations, which provide the work of certain speech mechanisms responsible for listening, speaking, reading and 
writing" (Leontiev, 2003).

Cause and effect links between words are considered to be the subject of psycholinguistics at the stage of its formation as a separated science based on the formula "incentive - associative link - reaction". A separated sound, syllable, word, word combination, sentence, text or extra-verbal element can be an incentive, and a word, phrase or text (associations) can be a reaction. Associative experiment based on this formula has become "an effective method of investigation of deep regularities in the lace of sensory correlations of general architectonics of the human mind" (Kovalevska, 2001). The mentioned formula is no less critical while learning a foreign language in the particular associative method. That is why it is quite logical to assume that namely deepening of associative links between the incentive and reaction can be an efficient direction of improvement of the process of foreign language learning, mastering vocabulary-grammar language structures. Involvement of emotional factors in the educational process can be one of the methods of deepening associative links.

The process of learning Ukrainian as a foreign language at higher educational institutions is extremely complicated from the point of knowledge integration (content component) and the point of specificity of communicative activity and heterogeneity of recipients (multi-ethnicity of student groups, different language levels, different level of English as an intermediary language). Due to gradual reduction of the number of learning hours provided for mastering the humanitarian component at non-humanitarian higher education institutions, including for studying Ukrainian as a foreign language, a teacher faces paramount and highly complex challenge: to stimulate the process of self-education of foreign students through the formation of personal interest of educational discipline, to activate their extra-classroom language activity that will allow to maintain appropriate level of high-quality language training of foreign students. In our opinion, the emotional component of studying process can be an essential factor for the formation of interest of a foreign student. The majority of modern pedagogues consider it an effective way to increase the effective studying, rationalization and optimization of the methodology of teaching. Also, it is necessary to note that the principle of emotionality belongs to basic principles of personal-oriented approach in studying.

Aim of the article is to analyze psycho-linguistic aspects of studying Ukrainian as a foreign language in the context of the interrelation of word and emotion; to outline ways of activation of an emotional factor in the process of studying Ukrainian as a foreign language.

Deep regularities of studying Ukrainian as a foreign language became the subject of investigation because of the actualization of the emotional sphere of a recipient, as well as the act of language activity of a foreign communicator.

Tasks of the research:

1. To carry out the theoretically-methodological analysis of directions of investigation of emotions in the process of didactics and communication;

2. To develop effective ways and methods of actualization of the emotional factor at classes of Ukrainian as a foreign language;

3. To investigate cultural peculiarities of perception of the emotional component of the educational process by different ethnic groups.

\section{Methods of the Research}

To achieve the aim the analysis of psycholinguistics works has been conducted with the help of system and structural methods. Also the following methods have been used: the method of psycho-linguistic analysis of intercultural communication in "a student - a teacher" and "a student - a student" dialogues while observing the interconnection of psychological phenomena, in particular, emotional sphere of a speaker and laws of formation and functioning of language units; method of pragmatic analysis during studying of the emotional component of the process of studying Ukrainian as a foreign language; descriptive method with ways of observation, comparison and generalization to form effective ways and methods to actualize the emotional factor at classes of Ukrainian as a foreign language; discourse-analysis (during analysis of extra-verbal methods of realization of the principle of emotionality of studying).

The empirical part of the research was conducted based on a questionnaire of foreign medical students of Higher State Educational Institution of Ukraine "Bukovinian State Medical University" to determine national peculiarities of perception of emotions in speech and educational process of representatives of different nationalities (students from India, Africa and Arabic countries).

Moreover, work hypothesis has been proposed in the research: emotional factors in studying Ukrainian as a foreign language promote the formation of the language picture of the world, significantly increase the efficiency of 
mastering the lexical composition of the language by a foreigner. The method of psycho-linguistic experiment has been used to prove the hypothesis, and activation of a particular area of the language picture of the world became a determinant directive.

\section{Literature Review}

To solve the outlined problem knowledge of psychology, psycholinguistics, rhetoric and intercultural communication are required. So modern scientists consider communicative act through the triad of such modes - logos (appeals to the content), pathos (appeals to feelings and emotions) and ethos (appeals to ethic norms and standards). The emotional component of communicative act is defined as the modus of pathos, while psycholinguists consider the correlation between components of three-component theory of lingual activity (lingual ability - lingual activity - language) as a primary subject of their researches.

For the first time Janet (1929) implemented a study of emotions in the process of cognition as a human reaction to their actions. American linguist Krashen (1982), while studying the specificity of studying a foreign language, emphasized on the need to cause exceptionally positive emotions, as only they can provide successful mastering of a foreign language. The scientist has formed the hypothesis of «superposition of the emotional filter» on the educational activity of learning a foreign language, especially at elementary stages. All scientists especially emphasize on the interconnection of emotional and cognitive spheres of personality. However, there is no single point of view on the question of the dominant role of one or another sphere among them. Thus, Spinoza (2016) believed that emotional sphere is subordinated to an intellectual one, as people can explain the nature of their emotions so that they can control them.

As the process of studying Ukrainian is a communicative act first of all, we must take into account the latest researches in psycholinguists about the nature of communication during the research of emotional factor in the process of studying it. Differentiation of studying of communicative acts is interesting for our research at such levels:

a) Neuro-psychological, which provides realization of brain organization of the process of communicative interaction;

b) Psycho-perceptive, presented by processes of social perception in the system of communicative relations;

c) Psycho-linguistic, where a transfer of information and feelings is occurred by language means;

d) Socio-psychological, where communication is considered as an instrument of socialization (Honcharuk \& Onufriyeva, 2018).

Our research is concentrated on two levels - psycho-linguistic and socially-psychological because firstly, a foreign medical student studies Ukrainian not only as means of acquirement of professional competency but as means to express their feelings, also language is a paramount instrument of socialization in Ukrainian speaking environment.

Fitsula (2002) singled out the principle of emotionality in the system of didactics principles. According to the author, its essence consists in causing a particular emotional state or feeling in a listener, stimulating successful mastering of knowledge. Holovska (1993) conducts psychological analysis of emotional components of didactics material in her dissertation. The system of psychological preparation of teachers has been developed concerning emotional situations modelling.

Throughout the last decades psychologists have investigated peculiarities of two types of human intellect: mental and emotional. That is why the concept of Kunitsyna (1993) is innovative from this point of view, as she proposed a new theory of social intellect, the scientist Dehirmengy (2013) developed an innovative emotionally-communicative method of intensive foreign language studying on its basis, integrated based on emotionally-motivational, cognitive and communicative components. This method is directed into the realization of such principles:

1) Consideration of individually-personal peculiarities;

2) Technology of intensive studying of a foreign language;

3) Stimulation of activation of the emotionally-communicative potential of personality;

4) Immersion into the lingual environment.

As emotions appear in the form of different emotional reactions and states, the appropriate mood is created, that is why teachers of Ukrainian as a foreign language should interpret the principle of emotionality as a didactic category that determines intellectual, volitional, aesthetics-emotional spheres of consciousness of students, forms their axiological approaches to learnt material in the process of teaching Ukrainian. Mastering a foreign language generates different psychological states: from the state of anxiety, irritation, uncertainty, alienation, indifference, emotional depletion to 
the state of emotional satisfaction, confidence. Absence of continuous progress in studying a language first of all causes state of irritation and then alienation and indifference. After students' loss of interest to the language learning, a peculiar invisible «wall» is built between teachers and students, due to it further educational interaction is reduced to the implementation of studying ritual of visiting lessons. In return, the natural feeling of the slightest progress in learning a language generates emotions of satisfaction, increases self-estimation of a student. Such continuous state conditions mood of personality (in psychology the mood is defined as a stable emotional state), in its turn, continuous positive mood forms the feeling of success in students, and common success of students and teachers forms the atmosphere of parity and productive educational cognitive activity.

While concentrating on causing students' positive emotions, it is not allowed to forget about the emotional personality of teachers themselves, as emotional flexibility is considered by the majority of scientists as one of the essential pedagogical competencies, psychologist Mitina (1998) defines it as an optimal (harmonic) combination of emotional expressiveness and emotional stability of a teacher. The problem of emotional flexibility of teachers is especially topical in a different ethnic audience of international students, where teachers can face the problem of religious intolerance or gender discrimination every minute. However, despite it, they must equally tolerate each student. Taking it into account, we want to emphasize on the importance of the emotional personality of teachers as a core in the organization of educationally-cognitive activity and as a creator of educationally-didactics materials (means of realization of the emotional principle of studying) in outlining strategies of activation of emotional component in the process of studying Ukrainian as a foreign language.

The recent research and the results indicate an important role of the emotional component in language learning (Table 1). On average, pleasure and Ideal Second Language Self are the most important.

Table 1. Descriptive Statics and Reliability Coefficients of Motivation and Emotion Variables (Saito, Dewaele, Abe \& In'nami, 2018).

\begin{tabular}{|c|c|c|c|c|c|}
\hline \multirow[t]{2}{*}{ Variables } & \multirow[t]{2}{*}{ Mean } & \multirow{2}{*}{ Standard deviation } & \multirow{2}{*}{$\alpha$} & \multicolumn{2}{|c|}{ 95\% Confidential Interval } \\
\hline & & & & Lower & Upper \\
\hline Ideal Second Language Self & 3.7 & 1.2 & 0.82 & 3.5 & 3.9 \\
\hline Ought-to Second Language Self & 3.0 & 1.1 & 0.85 & 2.7 & 3.2 \\
\hline Enjoyment & 4.5 & 0.8 & 0.83 & 4.4 & 4.7 \\
\hline Anxiety & 3.5 & 0.9 & 0.86 & 3.3 & 3.7 \\
\hline
\end{tabular}

The emotional component of the process of studying Ukrainian as a foreign language closely interacts with the psychological motivation factor of studying a language by a foreign student. In psychology, motives are divided into external, located beyond educational activity, and internal, directly depending on it. According to Leontiev (2003), namely internal motives, endowed with more significant incentive power in comparison with external ones, that is why they are more effective. Ponikarovska (2011) understands "internal motives" concept as "motives, which source is a deliberate cognitive need that is satisfied by educational activity. Cognitive motive grants this activity with personal meaning, studying a subject acquires individual value for a student because of it". It is necessary to note, that according to scientists, motivation is a dialectical unity of rational and emotional. Herewith, emotions are the core of the motivational structure of people.

Cognitive factor "is one that promotes intellectual development, reduction of the level of aggression and increasing of the level of tolerance for representatives of other cultures" and motivational factor, that "conditions aim of the activity, induces to study Ukrainian language, culture, the setting of contacts with representatives of other socio-cultural surroundings, analysis and acceptance of cultural differences between participants of communication" (Kostiuk, 2018).

Atanov (2003) considers emotion and will as basic psychological phenomena, which influence the character of educational activity in general, however, in our opinion, these phenomena form preconditions of successful communication in the broad meaning of this term in the process of activation of lingual activity. According to Pavlenko (2019), "studying of lingual activity, first of all, provides formation of motivational plan of need as necessary precondition of lingual activity in students, so communicative need appears as the source of lingual activity, it becomes the leading motive of human activity".

Zimniaya (1989) divides this opinion, defining lingual activity as "active, purposeful, motivated, the objective (content) process of giving and (or) receiving of formed and formulated idea with the help of language, directed into 
the satisfaction of communicative-cognitive needs of people in the process of communication". As we can see, the researcher slightly expands understanding of the need from "communicative" to "communicative-cognitive", considering communicative act in the context of cognitive linguistics.

Satisfaction or dissatisfaction of communicative need also generates positive or negative emotions, which influence communicative activity and educational process, as a consequence, the process of cognition in general. Not only positive but also negative emotions can occur during an educational activity, however, negative emotions not always have a lousy result for educational activity, as in many cases they can activate inner energy and purposefulness of a student. However, in our study we focus on positive emotions in the process of studying Ukrainian as a foreign language, in particular such as interest, surprise, curiosity, intensification of motivation to the process of studying, because these emotions are attributed by Vyhotsky (1991) to so-called "intellectual emotions", generated by intellectual activity. We want to note in this context that we regard studying a foreign language not only as an intellectual but as an emotionally-intellectual activity.

The process of studying Ukrainian as a foreign language is undoubtedly communicative interaction between foreign students and teachers, and according to scientific conclusions of current investigations, the efficient communicative interaction is determined by specific positive knowledge, in particular personal information about participants of communicative interaction (Mai, 2016).

\section{Results of the Research}

In teaching Ukrainian as a foreign language we distinguish the following methods to realize the principle of emotionality in studying:

1. Verbal (studying phraseological language level, songs, proverbs and sayings, idioms, use of scene texts, humour);

2. Extra-verbal (rate of speaking, intonation, gesticulation and facial expression);

3. Activity-playing (dialogues, role games "a doctor - a patient", "a doctor - an intern".

While analyzing verbal groups, it is necessary to emphasize that essential vocabulary for medics is mostly emotionally marked. "Key semantic oppositions health - illness, which occupy a prominent place in the axiological image of the world of a modern doctor and take a diametric position on the value - anti-value opposition according to the results of analysis" (Leshchenko \& Zhovnir, 2018). Besides, inner form, motivation is often based on the nomination of a medical term. Knowledge of inner form generates positive emotions in students because of knowing the genesis, originals of word creation. For example, while studying medical terms, it is necessary to accent on the derivatives: clamp - from "to clamp", pincers - from "to pinch", height meter - from "to meter height", etc.

Activity-role techniques are the most effective during the development of dialogical and monological communication of medical students in pair "a doctor - a patient" in the process of conduction of professional dialogue. However, such dialogue is possible at B1-B2 levels, as it provides knowledge of professional vocabulary, that is why it is possible to propose dialogues on popular science or socio-cultural topics at first courses. Method of designing possesses considerable emotional potential, as it allows students to reveal their creative abilities, talents/ For example, creation of the project "video-excursion around the city where I live" (video record and then its voice); doing an interview, creating PowerPoint presentations ("My life in Ukraine", "My native country", "My family", "Holidays in my country", "Tourist places in my country"). It is necessary to note here that it is easier to present something own in an emotional and content plan for students, demonstrating a feeling of national pride, rather than reveal topics connected with Ukraine.

Using a role game through the peculiarity of "transformation" immanently provides a factor of emotionality. Besides the formation of skills to have a professional dialogue with a patient, the role game develops communicative skills, trains the feeling of self-confidence, motivates to educational activity, increases the level of language practice and destroys communicative barriers. Method of the role game at Ukrainian as a foreign language classes is one of the main methods of realization of communicative activity and personally-oriented approaches to studying. However, a teacher should pay attention to the compliance of principles of tolerance, especially at different ethnic groups during the use of this method. For example, we offer exercises for the development of dialogical communication while studying the communicative topic "Human senses" (See Appendix A). Phraseological units, proverbs and sayings are empowered with particular emotional potential, as they are peculiar "clots of emotions" by their nature, representatives of a language picture of the world. Medical students need to select professionally coloured phraseological units or those which are connected with parts of the body. For example, while studying the communicative topic mentioned above, we offer exercises for mastering of the phraseological level of Ukrainian 
language (See Appendix B). Informative component of educational material also becomes effective means of realization of the emotional principle of studying, however, when presenting interesting popular scientific information, for example, implementation of grammar exercise is proposed based on little-known medical facts (See Appendix C).

Expression of personal position about a particular dilemma or significant socially meaningful problem can generate a feeling of competition, so it means to cause emotional excitation. As searching for arguments for a discussion excites the mental activity of students, cause the desire to self-affirm through a word. That is why teachers need to formulate a question for a discussion so that immediately interest students' attention by a proposed problem. In our opinion, there are the most efficient ways of formulation of discussion topics, such as an alternative question, use of "philosopheme", idioms, proverbs, presentation of positive "leading" scientific information (See Appendix D).

As a Ukrainian as a foreign language class is often the embodiment of texts-centric didactics model, work with a text is a crucial stage in the educational activity. Firstly, the text theme is essential for medical students. And that is why we propose to orient on popular science texts of the medical sphere. Also the efficiency of using texts as means of formation of communicative competency is possible under such conditions: adaptation of texts to appropriate language level of students, the optimal amount of words for the understanding of a text and correlation of known and new vocabulary, using active (even of the most frequent) vocabulary composition of a language, plot of text or using text with open final, which provides an individual continuation of the story by students, the formation of text from its separate fragments and so on. The plot of texts or text with an open final is usually combined with the realization of the principle of emotionality. For example, texts in the form of letters or diaries cause particular interest in students. Also texts in the form of letters are endowed with emotional potential, which is with the specific plotline of the described event and outlined phrases for further collective discussion (See Appendix E).

The positive atmosphere of a lesson can be adequately supported by a good sense of teacher's humour. According to researches of psychologists, laughter can activate the tired brain to strengthen the process of concentration in students. Humour can be considered as appropriate jokes, quotation of funny examples from life or professional medical sphere, however, it is necessary to remember, that humour usually has national spesifics, that is why not everything that makes a Ukrainian laugh will be adequately accepted by a foreigner. Besides, teachers must remember particular "conditional" list of taboo topics, defined by ethics of intercultural communication, which are not allowed to be joked in any case (topics of race, beliefs etc.).

According to the conclusion of psycholinguists, the type of communication depends on mental qualities of personality, the culture of society, where the person was growing up, and personal values, which originate from the mentality of society (Kim, Joshanloo \& Foldesi, 2018). Moreover, as the lesson is a communicative act, then the embodiment of "Me-characteristics" of a foreign student at Ukrainian as a foreign language classes primarily depends on mental qualities of personality. To confirm this hypothesis, the empirical part of the research is based on Higher State Educational Institution of Ukraine "Bukovinian State Medical University", in particular, the survey of foreign medical students has been conducted to detect national peculiarities of perception of emotions by the representative of different nationalities (students from India, African and Arabic counties). Survey in the form of the questionnaire of closed type was conducted at the first and third courses. In general, 120 students were respondents (about 60 of the courses and about 20 representatives of separate nationality). For the clarity of the experiment an equal percentage of respondents has been complied in the quantitative aspect of ethnic groups and by gender feature. The majority of all ethnic groups thinks that emotions promote better and much longer memorizing of new words and phrases in the learning Ukrainian (93\% - Arabic students, 90\% - Africans, 86\% - Indians). In gender aspect, emotional presentation of educational material is positively accepted by male respondents of Arabic countries ( $93 \%$ against $64 \%$ female respondents) and female respondents of African countries (88\% against $73 \%$ of the male respondents), and almost balanced gender perception among Indians (74\% of male and $76 \%$ of the female respondents) (See Figure 1 and Figure 2). 


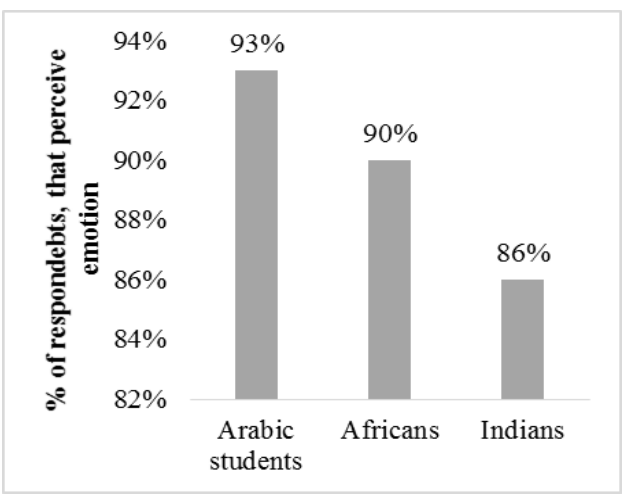

Figure 1. Respondents that perceive emotions in learning process, $\%$

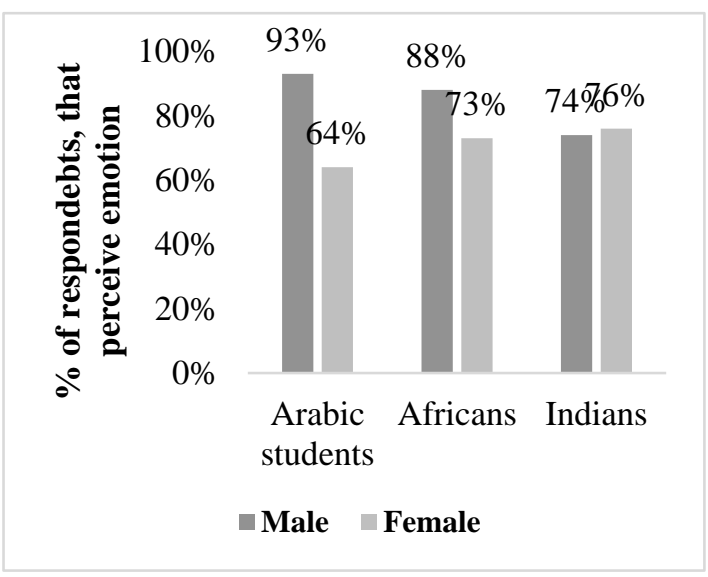

Figure 2. Respondents that perceive emotions in learning process by gender, $\%$

Another part of respondents neutrally perceives emotions in studying Ukrainian, and only $7 \%$ of Indians - negatively (because they consider Ukrainian grammar too complicated for studying). Comparative analysis of students-respondents from the first and third courses represents an exciting picture. Because, as an extra-verbal expression of emotions is not nationally marked in the majority of cases (however, there are unusual cases, for example, negative shaking of the head, that is inherent in the majority of nationalities, is the conciliatory gesture for people from Morocco), then the verbal realization of the principle of emotionality requires a certain level of language knowledge (appropriate vocabulary is necessary for the understanding of proverbs or humour, as well as knowledge of lingual etiquette and at least elementary level of feeling of so-called "universe" of language).

The survey has demonstrated, that emotions are means of activation of attention for first-year students (61\% of all respondents), way of better memorizing of new words or phrases $(28 \%)$ and way of formation of associations (including an inner form of a word) $-11 \%$. While we observe diametrically opposite picture at the third course, as the formation of associations becomes the basic desired result of the emotional principle of studying for third-year students $(58 \%)$. At the same time, mastering vocabulary, emotions are means of activation of attention (34\% from all respondents), way of better memorizing of new words or phrases (8\%). There are almost no national differences in perception of the emotional principle of studying in this part of the survey (See Figure 3). 


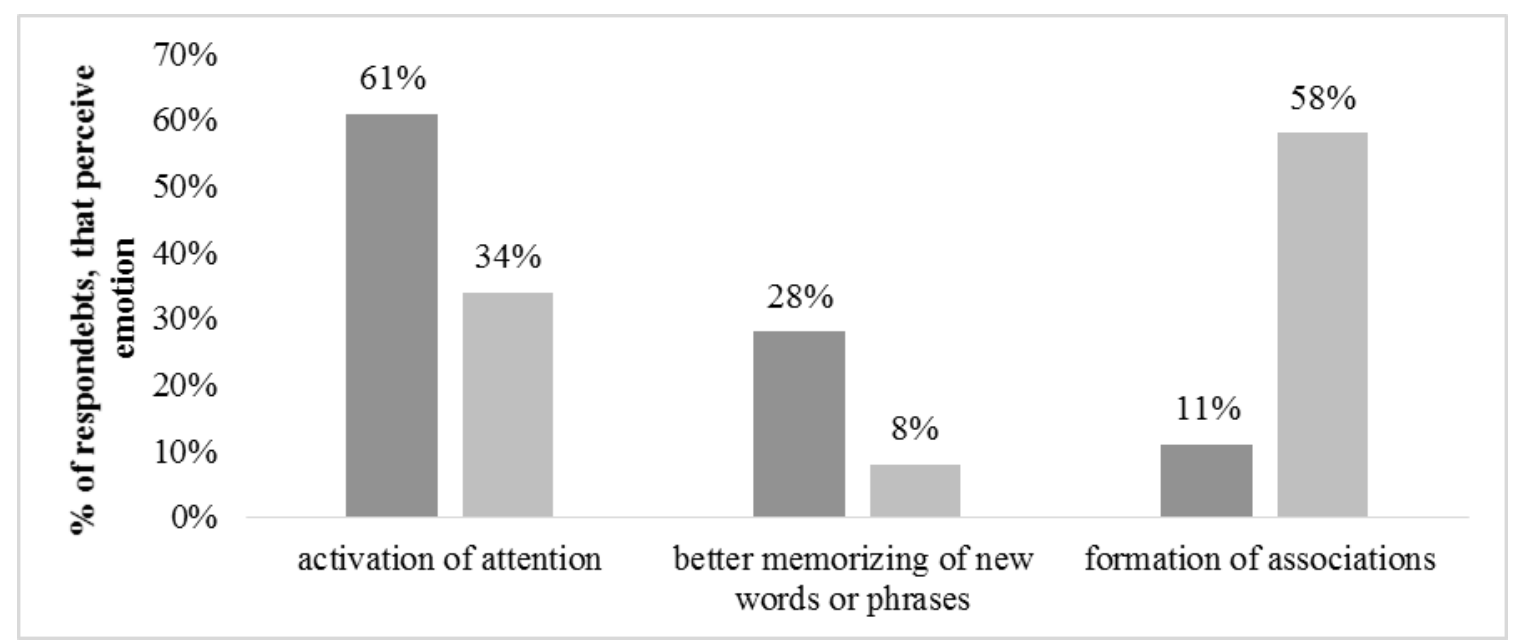

Figure 3. The distribution of students answer for the questions about role of emotions in learning process

The psycho-linguistic experiment has been conducted for confirmation of nominated hypothesis about that emotional factors in studying Ukrainian as a foreign language promote the formation of the language picture of the world, significantly increase the efficiency of vocabulary assimilation by foreigners. Two different ethnic groups of foreign students from the third course took part in the experiment at Higher State Educational Institution of Ukraine "Bukovinian State Medical University" with a relatively equal language level. Communicative topic "Blood. Donor. Blood groups" was proposed for studying at both groups, basic vocabulary and keywords were defined; however, the way of presenting material was different. Emotionally neutral educational material was selected for the first group for mastering of essential vocabulary and phrases. The system of lexical-grammatical exercises, texts for reading and listening were directed into the activation of the emotional sphere of students in the other group, namely lexical minimum is weaved to the topic on the background of emotionally coloured texts, phraseological units, proverbs, idioms, quotes of famous people, concentration on the inner form of words etc. Including scientific conclusions of modern psycholinguists that mechanisms of language are formed in the result of the implementation of the lingual activity, which provide perception during listening, reading and generating the lingual product during speaking and writing (Leontiev, 2003). The results of the psycho-linguistic experiment were checked at two stages: at the first stage, the level of assimilation of keywords, phrases, understanding of them and perception in live communication was examined, at the second stage - the ability of students to produce their text (written and oral) with the use of essential lexical minimum. Percentage comparison of the received results has proved, that level of basic vocabulary assimilation was higher in $13,6 \%$ in the group where educational material was presented based on the emotional principle of studying, and the level of correct, logical use of this vocabulary in oral and writing communication - in $14,1 \%$, that proves validity and relevance of the emotional principle of studying a foreign language, in part Ukrainian.

\section{Discussion}

Ac Some researches substantiate an emotionally-value component of the content of modern education (Mitina, 1998; Vyhotskyi, 1991), the principle of positive emotional background during realization of inter-cultural communication (Kostiuk, 2018). However, problems of activation of emotional factor or emotional components in didactics process are not explored enough yet, and the problem of realization of the emotionality principle in the teacher's work with international students in varied ethnic groups is studied for the first time in modern Ukrainian pedagogy, that determines topicality of this study.

"Emotions are very important for foreign language acquisition. During the language learning process, the appearance of emotional walls can hinder learner development. These barriers can be reinforced with different emotions, such as anxiety and low self-esteem" (Agaësse, 2017). "Emotional factors and foreign language teaching are closely related. Such practice has proved that the solution of emotional problems is helpful to improve the students' learning effect and develop the function of positive emotions such as self-esteem, confidence and motivation" (Wang, 2016).

"Emotions are contextually and socially constructed, they can shift the emotional mood within the classroom more generally and affect the emotions of the teacher" (Smith \& King, 2018). The literature studies such emotional components as anxiety and satisfaction, which negatively or positively impact the success in learning foreign 
languages (Saito et al., 2018). Our results confirm the importance of taking into account the emotional factor in foreign language learning.

\section{Conclusions}

To sum up, the emotional stimulation belongs to efficient methods of activation of communicative and therefore, educational activity. It has been proved that satisfaction or dissatisfaction of communicative need of a foreign student generates positive or negative emotions, which influence communicative activity, educational process and the process of cognition in general. It has been defined that the causes of negative emotions in the process of studying Ukrainian as a foreign language, such as disappointment, indifference, concern, fear and alienation, lead to the following consequences: students do not see their progress in learning a language, they have difficulties in understanding a language by hearing and a vast synonymous potential of the Ukrainian language. The group of efficient methods to ensure emotionality of studying has been distinguished: verbal, extra-verbal and activity-role.

In the process of study such specific strategic conditions were formed for studying by foreign students, concerning realizing the principle of emotionality in studying in multicultural polyethnic students' audience:

- We consider cultural, personally-oriented, communicative-activity approaches as the most optimal ones for the realization of the principle of emotionality in studying Ukrainian as a foreign language;

- There is one essential task for a teacher at a Ukrainian as a foreign language class: to create «relaxed» communicative field for the expression of the originality of each personality among foreign students (mental, ethnocultural, values peculiarities);

- It is important to form a psychologically-communicative and emotional rapport with multicultural polyethnic audience through the direction of the communicative content component of a class on "Me-characteristics" of a student, in the particular possibility of presentation of "Me-concept", "Me-image" and self-estimation;

- The teachers should provide the organic unity of logically-analytical and emotionally-aesthetic means in educationally-methodological materials and speech manner of a teacher, development of creative thinking of students;

- Teachers must focus on neutral communicative topics, which will unite students for the development of dialogical and monological communication, in return, it is necessary to avoid sharp topics: religious, race, in some cases historical (periods of colonialism in the history of African countries and India, controversial periods of common Ukrainian-Polish history);

- Activation of students' attention with the help of verbal and extra-verbal methods of studying (setting of rhetorical questions, moderate gesticulation, use of jokes, humour, phraseology, immersion into the inner form of words, etc.) is required.

Improvement of strategies formulated above concerning development of emotional sphere and emotional intellect in the process of studying Ukrainian as a foreign language is prospects for further investigations.

\section{References}

Agaësse, J. (2017). Emotional dimensions in learning: Emotions in the foreign language class. Eruditi: The CGCS Journal of Language Research and Education, 1(1), 48.

Atanov, H. A. (2003). Revival of didactics is the ground of the high school development. Theory and methods of learning fundamental disciplines in high school, 1(1), 8-27.

Dehirmengy, E. V. (2013). Emotionally-communicative method of intensive education of foreign language by students: results of approbation. Science and education, 4, 14-18.

Fitsula, M. M. (2002). Pedagogy. Kyiv, Ukraine: Akademiya.

Holovska, I. H. (1993). Emotional components of didactics material as condition of development of educational activity. PhD dissertational thesis. National Academy of Educational Sciences of Ukraine, Institute of Psychology, Kyiv, Ukraine.

Honcharuk, N., \& Onufriyeva, L. (2018). Psychological analysis of levels of formation of communicative actions. Psycholinguistics. Series: Psychology, 24(1), 97-117. https://doi: 10.31470/2309-1797-2018-24-1-97-117

Janet, P. M. F. (1929). LíEvolution de la personnalité [The evolution of personality]. Paris, France: Chahine.

Kim, M. Y., Joshanloo, M., \& Foldesi, E. (2018). Relationship between emotional expression discrepancy and life satisfaction across culture and personal values. Current Psychology, 39, 1087-1097. https://doi.org/10.1007/s12144-018-9826-6 
Kostiuk, S. S. (2018). Development of competencies of intercultural communication of foreign students at the basic stage of studying of Ukrainian language. PhD dissertational thesis. Borys Grinchenko Kyiv University, Kyiv, Ukraine.

Kovalevska, T. Y. (2001). Communicative aspects of neuro-linguistic programming [monography]. Odesa, Ukraine: Astroprynt.

Krashen, S. D. (1982). Principles and Practice in Second Language Acquisition. Oxford, UK: Pergamon.

Kunitsyna, V. N. (1991). Difficulties of intrapersonal communication. Doctoral dissertation thesis. St. Petersburg State University, St. Petersburg, Russia.

Leontiev, A. N. (2003). Basis of psycholinguistics. Moscow, Russia: Smysl.

Leshchenko, T., \& Zhovnir, M. (2018). Health vs. illness in the context of verbal representation of holistic picture of the world of modern doctor. Psycholinguistics, 24(2), 163-180. https://doi.org/10.31470/2309-1797-2018-24-2

Mai, J. E. (2016). Personal information as communicative acts. Ethics and Information Technology, 18(1), 5-57. https://doi.org/10.1007/s10676-016-9390-4

Mitina, L. M. (1998). Psychology of professional development of a teacher. Moscow, Russia: Flinta.

Pavlenko, O.M. (2019). Teaching of Ukrainian language in the process of propaedeutic preparation of foreign students as linguodidactic problem. Kyiv, Ukraine: NTUU "KPI".

Ponikarovska, S. V. (2011). Psychological factors of studying of students at higher educational institutions. Pedagogical education: theory and practice, 8, 241-245.

Saito, K., Dewaele, J. M., Abe, M., \& In'nami, Y. (2018). Motivation, emotion, learning experience, and second language comprehensibility development in classroom settings: A cross-sectional and longitudinal study. Language Learning, 68(3), 709-743. https://doi.org/10.1111/lang.12297

Smith, L., \& King, J. (2018). Silence in the foreign language classroom: The emotional challenges for L2 teachers. In A. J. Martínez (Ed.), Emotions in second language teaching, 323-339. Cham, Switzerland: Springer. https://doi.org/10.1007/978-3-319-75438-3_18

Spinoza, B. (2016). The Collected Works of Spinoza, Volume I. Princeton, NJ: Princeton University Press. https://doi.org/10.1515/9781400873609

Vyhotsky, L. S. (1991). Pedagogical psychology. Moscow, Russia: Pedagogika.

Wang, Y. (2016). Research on the Embodiment of Emotional Factors in English Teaching. In Y. Su, G. Chang, \& Z. Luo (Eds.), Proceedings of the 2016 International Conference on Education, Management, Computer and Society, 1520-1524). Amsterdam, Netherlands: Atlantis Press. https://doi.org/10.2991/emcs-16.2016.381

Zimniaya, I. A. (1989). Psychology of studying a foreign language (On the material of Russian as a foreign language). Moscow, Russia: Russkiy Yazyk. 


\section{Appendix A}

\section{Combine utterances}

Which human organs never stop growing?

Human needs a minimum of 1000-1500 calories a day.

Which amount of energy is necessary for human?

You waste 27 calories during a kiss.

In order to make one step, you use 200 muscles.

Nose and ears of human never stop growing.

How does skeleton change throughout life?

That is why running and sport walking are such effective for training.

Does human waste energy when kissing?

Children are born with 300 bones, but the amount gets smaller with age.

\section{Appendix B}

\section{Remember useful phrases and their meaning. Make up sentences with them.}

- To keep your nose in the wind - to be ready for changes;

- Falcon vision - sharp vision;

- Different strokes for different folks - each person has individual tastes;

- A good nose - good sense of smell that feels any tiny changes.

\section{Appendix C}

\section{Put words in brackets in the correct form:}

1. There are about 2000 (taste receptor) in a human (organism). The tongue is the strongest muscle in (human organism)

2. Women blink in about 2 (time) more often than men.

3. It is not possible to sneeze with (open eyes).

4. The human eye can differentiate 10000000 (colour).

5. People with (blue eyes) are more sensitive to pain than other people.

6. Men suffer from (colour-blindness) in about ten times more often than women.

\section{Appendix D}

1. Scientists say: «Eye does not see, the ear does not hear, the nose does not feel, but a brain!» How do you understand it?

2. Why do people have two ears, but one mouth?

3. A kiss - is not only a display of your sincere feelings but also exchange of about 300 varieties of bacteria. So, a kiss - is a significant danger, isn't it? Do you agree with this opinion? 


\section{Appendix E}

\section{Read the letter of Francisca. How do you understand underlined words in the text?}

Dear Samantha!

Guess where I am? You will not believe it! I am at the state hospital! Do you know what has happened? I have broken my arm! However, don't worry - I am okay.

It happened yesterday in the evening at "hundred-meterrace". I hurried because it was late and I needed to catch the last bus. It was slippery on the street. I slipped and fell.

My friends are with me in the hospital. They don't leave me alone. They help and entertain me. Friends brought me a lot of fruit and sweets. It is true that a friend in need as a friend indeed. I am happy that I have true friends!

The doctor made a round in the morning and said that my arm would be as good as new. The nurse takes care of me all the time.

Yesterday I made an X-ray, and the doctor said that I had a simple fracture. He put on plaster on my arm. Furthermore, he said, that time is the best healer. I will be at home in several days, and I will come to the hospital for consultation and bandaging.

How are you? Write to me about your news. I hope that you and your family is okay.

Best wishes,

Francisca 